\title{
Küresel İklim Değişikliğinin Kaçınılmaz Sonucu: Kuraklık
}

\author{
Nur Sinem PARTIGÖç ${ }^{1}$ ve Sevde SOĞANCI ${ }^{2}$
}

\section{Öz}

Küresel iklim değiş̧ikliğinin sebep olduğu önemli olaylardan biri de kuraklıktır. Tekrar edebilen, bir veya birden çok mevsime yayılan, azalan yağışlar ve artan sıcaklıklar nedeniyle oluşan ve su varlığına bağlı olarak tüm doğal kaynakları etkileyen bir doğal afet türü olarak tanımlanmaktadır. Ancak küresel iklim değişikliğine bağlı olarak dünya üzerinde aşırı artan sıcaklık ve azalan yağışlar kuraklığın sürekliliğini ve olası olumsuz etkilerini arttırmaktadır. Kuraklık ile mücadele süreci, bu afetin çok yavaş başlaması aylar ve hatta yıllar boyu kümülatif olarak çok geniş alanları etkilemesi sebebiyle diğer doğal afetlere göre çok daha zordur. İlk olarak tarım alanlarında etkisini gösteren bu afet türünün, tarım sektöründe gözlenen etkilerinin diğer sektörlerden çok daha farklı olduğunu söylemek mümkündür. Bu duruma temel oluşturan sebepler arasında çiftçilerin topraktan yeterli verimi alamaması, su havzalarının yeterince korunamaması ve kentlerin kırsal alana baskı yapması sonucu tarım topraklarının amaç dışı kullanılması gösterilmektedir. Türkiye konumu itibariyle küresel ısınmanın etkilerinden en fazla oranda etkilenecek ülkeler arasında yer almaktadır. Bu sebeple, kent planlamada ve sürdürülebilir afet yönetimi süreçlerinin ortak öznesi durumunda olan iklim değişikliği ve tarım sektörü etkileşimi politika ve stratejilerin geliştirilmesi sürecinde öncelik verilmesi gereken konulardan biridir. Alınacak önlemler ve geliştirilecek doğru stratejiler sayesinde kuraklığın etkisiyle meydana gelebilecek önemli ve canlı yaşamını direkt olarak etkileyen çevresel problemler ciddi şekilde bertaraf edilebilir. Yakın gelecekte olası bir kuraklık sonucunda etkilenecek bölgelerin önceden tespit edilmesi ve gerekli önlemlerin alınabilmesi için Coğrafi Bilgi Sistemleri (CBS) ve Uzaktan Algılama (UA) gibi etkin yöntemlerin kullanılması atılacak adımlar arasında yer almaktadır. Bu çalışma kapsamında kuraklıkla etkin biçimde mücadele edilebilmesi adına CBS ve UA teknikleri kullanılarak geliştirilebilecek önlemler ve kentsel politikalar üzerinde durulmuştur.

Anahtar Kelimeler: Kuraklık, tarım, afet yönetimi, kentsel politikalar

\section{An Inevitable Consequence of Global Climate Change: Drought}

\begin{abstract}
The drought is one of major natural events caused by climate change. It is defined as a type of natural disaster that can recur, spread over one or more seasons, occurs due to decreasing rainfall and increasing temperatures, and affects all natural resources depending on the presence of water. However, extreme rising temperatures and decreasing rainfall affect the continuity and potential negative consequences due to global climate changes. The process of disaster recovery for drought is much more difficult than other natural disaster types. Because the drought occurs very slowly, takes long times months and even years and affects very large areas cumulatively. It is possible to say that the effects of this disaster type on agriculture sector are so different from other sectors. Among main reasons, there

\footnotetext{
${ }^{1}$ Dr. Öğretim Üyesi. Pamukkale Üniversitesi, Mimarlık ve Tasarım Fakültesi, Şehir ve Bölge Planlama Bölümü, Denizli, Türkiye.

${ }^{2}$ Pamukkale Üniversitesi, Mimarlık ve Tasarım Fakültesi, Şehir ve Bölge Planlama Bölümü, Denizli, Türkiye.

* Corresponding author/ İlgili yazar: spartigoc@gmail.com
}

Gönderim Tarihi / Submission Date: 12.09.2019

Kabul Tarihi / Acception Date: 19.12.2019
\end{abstract}


exist the lack of sufficient yield from the soil, the lack of adequate protection of watersheds and the misuse of agricultural lands as a result of the pressure of urbanization. Turkey is one of the countries that global climate change affects critically. For this reason, the integration between climate change and agriculture sector as a common subject of urban planning and sustainable disaster management should be given priority in the development of policies and strategies. Due to the potential precautions and policies, significant environmental problems that may occur because of the impact of drought and which directly affect living life can be eliminated in a serious way. There exist common methods such as Geographic Information Systems (GIS) and Remote Sensing (UA). These methods are certain ones to determine the regions that will be affected by a possible drought in the near future in advance and to take the necessary measures. In the scope of the study, precautions and urban policies with using GIS and UA are discussed that can be developed in order to struggle drought effectively.

Keywords: Drought, agriculture, disaster management, urban policies

\section{GiRiş}

İnsanlar var olduğu günden bu zamana kadar dünya coğrafyası sürekli değişime uğramış, bu değişimlerle beraber doğal dengedeki bozulmalar birbirini takip etmiştir. Nitekim iklim değişikliğinde konusunda geçmiş dönemlere baktığımızda meteorolojik koşulların sürekli olarak değiştiğini ve kendisiyle beraber pek çok problemi (sosyo-ekonomik, çevresel, toplumsal, vb.) beraberinde getirdiği ortadadır (Öztürk, 2012). Sanayi Devrimi'nin iyiden iyiye hissedildiği 1850'li yıllardan 2000 yılına kadar dünya genelinde ortalama $1^{\circ}$ lik ısı artışı kaydedilmiş ve bu değişime bu dönemde hızlanan fosil yakıt kullanımı, sanayileşme, hızlı nüfus artışı ve ormansızlaşmanın neden olduğu olduğu bilinmektedir. 21. yüzyılda dünyanın iklim sisteminde bozulmaların olduğu bütün iklim bilimciler tarafından kabul edilmektedir. Doğal dengenin bozulması konusunda önemli rolü olan insanoğlunun gerekli önlemleri almaması ve bu dengenin bozulmasına sebep olan faaliyetleri aynı biçimde ve yoğunlukta sürdürmesi halinde, gelecekte, küresel ısınmaya bağlı olarak iklimdeki bozulmaların ve yaşamsal etkilerinin artacağı öngörülmektedir (Sırdaş, 2003; Öztürk, 2012).

Küresel iklim değişikliğinin sebep olduğu önemli olaylardan birisi de kuraklıktır. Kuraklık, genel ifadeyle, normal ve tekrarlayan, bir veya birden çok mevsime yayılan, azalan yağışlar ve artan sıcaklıklar nedeniyle oluşan bir iklim olayıdır. Ancak küresel iklim değişikliğine bağlı olarak dünya üzerinde aşırı artan sıcaklık ve azalan yağışlar kuraklığın sürekliliğini ve olası olumsuz etkilerini arttırmaktadır (Akbaş, 2014). Dünya üzerinde toplam 31 doğal afet türü bulunmakta ve bunlardan 28'inin meteoroloji ile ilgili olduğu bilinmektedir. Bu doğal afet türleri içerisinde en tehlikeli olanlardan biri de kuraklıktır. Kuraklık ile mücadele süreci, bu afetin çok yavaş başlaması ve çok geniş alanları etkilemesi sebebiyle diğer doğal afetlere göre çok daha zordur. Kuraklık tüm iklim kuşaklarında görülen bir doğa olayıdır ancak bölgenin kuraklığa karşı olan hassasiyeti ve etki derecesi bölgeler arası farklılıklar göstermektedir (Kapluhan, 2013). Türkiye'nin coğrafi konumu, değişkenlik gösteren iklim yapısı, bölgesel olarak değişen topografik koşullar ve orografik özellikleri nedeniyle ülke sınırları içerisinde bölgeler arasında iklim özellikleri bakımından ciddi farklıııklar olduğu gözlenmektedir. Örneğin kurak ve yarı kurak bölgeler (Güney Doğu ve İç Anadolu bölgeleri gibi) ve yeterli suya sahip olmayan yarı nemli bölgeleri (Ege ve Akdeniz bölgeleri gibi) kuraklık tehdidi bakımından aynı düzeyde olmayan bölgelerdir (Türkeş, 2012; Öztürk, 2012).

Kuraklığın meydana gelmesi halinde, öncelikli olarak tarım alanlarında ve su varlığına bağlı sektörler üzerinde önemli değişimler gözlenmektedir. Şöyle ki, olası kuraklık olaylarının yaşanması halinde, tarımsal faaliyetlerin yürütüldüğü alanlarda toprakta meydana gelecek 
verimsizlik, bitkinin ihtiyacı olan suyu alamaması, tarımsal üretimin zayıflaması ve tarım alanlarının amaç dışı kullanımı gözlenecek olası sonuçlar arasında yer almaktadır (Başoğlu ve Telatar, 2013; Akbaş, 2014). Bu durum mevcut arazi kullanımının bozulmasına ve yapılaşmanın tarımsal faaliyetlerin sürdürüldüğü alanlara ilerlemesine sebep olacaktır. Kentleşme süreçlerinin doğal alanlarda gözlenen afet risklerinden bağımsız düşünülemeyeceği ortadadır. Planlama araçları (arazi kullanım planlaması, arazi yönetimi, sürdürülebilir modeller, vb.) kullanılarak alınacak önlemler ve geliştirilecek politikalar sayesinde kuraklığın etkisiyle meydana gelebilecek su kıtlığı, bitki çeşitliliğinde daralma, tarım topraklarının kentleşme baskısı altında kalması gibi önemli ve canlı yaşamını direkt olarak etkileyen çevresel problemler ciddi şekilde bertaraf edilebilir. İşte bu noktadan hareketle, bu çalışma kapsamında kuraklıkla etkin biçimde mücadele edilebilmesi adına Coğrafi Bilgi Sistemleri (CBS) ve Uzaktan Algılama (UA) teknikleri kullanılarak geliştirilebilecek önlemler ve kentsel politikalar üzerinde durulmuştur.

\section{IKLLIM DEĞişiKLIĞiNiN KAÇINILMAZ SONUCU: KURAKLIK KAVRAMI}

Kuraklık kavramı, yağışların kaydedilen normal seviyelerinin altına düşmesi sonucu arazi ve kaynaklarının olumsuz etkilenmesine ve hidrolojik dengenin bozulmasına sebep olan doğal olayı olarak tanımlanabilir (Sırdaş, 2002). Temelinde bir doğa olayı olarak belirtilen kuraklık küresel iklim değişikliğine bağlı olarak aşırı artan sıcaklık ve azalan yağışların normalden çok daha fazla olması ve kuraklığın sürekliliğinin devam etmesi durumlarında bir doğal afet türü olarak ifade edilmektedir. Dünya üzerinde gözlenen toplam 28 çeşit meteorolojik afet türü arasında en önemli olanlardan biri kuraklıktır (Kadıoğlu, 2001). Meteoroloji Mühendisleri Odası (MMO) tarafından 1999 yılında yayınlanan rapora göre, dünya genelinde görülen doğal afetlerin büyük bir kısmını meteoroloji karakterli afetlerin oluşturduğu ve bu tip afetler arasında çeşitli karakteristik özellikler (şiddet, etkili olduğu süre, etkilediği toplam alan, toplam can kaybı, vb.) bakımından kuraklığın ilk sırada yer aldığı vurgulanmıştır (MMO, 1999). Tablo 1'de doğal afetlere ilişkin dünyadaki doğal afetlerin karakteristik özellikleri ve çeşitli etkilerinin puanlanmasına göre önem sıraları gösterilmiştir.

Tablo 1. Dünyadaki Doğal Afetlerin Karakteristik Özellikleri ve Çeşitli Etkilerinin Puanlamasına Göre Önem Sırası (Kaynak: Bryant, 1993; Aktaran: MMO, 1999)

\begin{tabular}{|c|c|c|c|c|c|c|c|c|c|}
\hline \multirow[b]{2}{*}{ titum } & \multirow[b]{2}{*}{ Attet } & \multicolumn{6}{|c|}{ 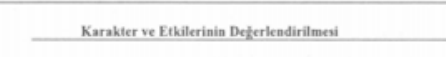 } & \multirow[b]{2}{*}{ 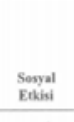 } & \multirow{2}{*}{ 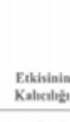 } \\
\hline & & 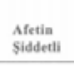 & 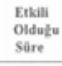 & 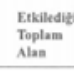 & 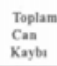 & & tomentix & & \\
\hline & & & & & & & & & \\
\hline $\begin{array}{l}4.5 \\
6.5 \\
6.9\end{array}$ & $\begin{array}{l}\text { Defrem } \\
\text { Dothe } \\
\text { Onta entem }\end{array}$ & & & & & & & & \\
\hline 8. & 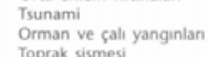 & & & & & & & & \\
\hline 竞: & 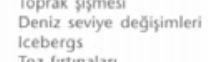 & & & & & & & & \\
\hline $\begin{array}{l}1.4 . \\
1.4 \\
4.4\end{array}$ & 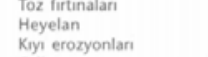 & & & & & & & & \\
\hline 16. 16. & $\begin{array}{l}\text { chigepssolituction } \\
\text { crion }\end{array}$ & & & & & & & & \\
\hline 18. & 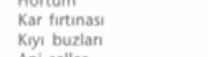 & & & & & & & & \\
\hline $\begin{array}{l}21 \\
22 \\
22 \\
2.2\end{array}$ & 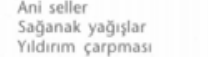 & $\begin{array}{l}3 \\
4 \\
4\end{array}$ & & & 4 & & & & \\
\hline $\begin{array}{l}2.3 . \\
25 . \\
25 .\end{array}$ & 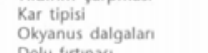 & $\begin{array}{l}4 \\
4\end{array}$ & & ${ }_{2}^{4}$ & 4 & & & & \\
\hline 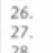 & 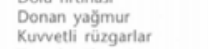 & $4_{5}^{4}$ & ${ }_{4}^{4}$ & $\begin{array}{l}3 \\
3\end{array}$ & 3 & & ${ }_{5}^{4}$ & 5 & \\
\hline 20 & 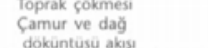 & & & & 5 & & & & \\
\hline 31. & 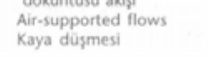 & ${ }_{5}^{4}$ & $\begin{array}{c}3 \\
5\end{array}$ & s & ${ }_{5}^{4}$ & & 5 & $s_{5}^{5}$ & \\
\hline
\end{tabular}


Kuraklık, meydana getireceği zararlar ve halkın bu konuda yeterince bilgi sahip olmaması gibi nedenlere bağlı olarak en önemli doğal afetlerden biri olarak kabul edilmektedir ve 'doğanın gizli tehlikesi' olarak adlandırılabilir (Şimşek ve Çakmak, 2010). Kuraklığın bazı durumlarda bir mevsim sürüp dar alanları etkileyebileceği, bazı durumlarda ise senelerce devam edebileceği ve geniş alanları etkileyebileceği görülmektedir. En genel biçimiyle denilebilir ki, kuraklık, başlangıç ve bitiş tarihinin belirsiz oluşu, kümülatif olarak artış göstermesi, aynı anda birden fazla kaynağa olan etkisi ve ekonomik boyutunun yüksek olması gibi özellikleri sebebiyle diğer doğal afetlerden ayrımaktadır. Kuraklığı diğer doğal afetlerden ayıran bir diğer özellik ise, insan faaliyetleri ile yakından ilişkili olmasıdır (URL 1, 2019).

Su kaynaklarının bilinçsiz kullanımı ve beklenen yağışların meydana gelmemesi durumunda, bu kaynak türünün beklenen talebi karşılayamadığı ve kuraklığın kendini hissettirmeye başladığı görülmektedir. Türkiye açısından değerlendirildiğinde, ülkemiz yarı nemli orta enlem bölgesinde bulunmaktadır. Konumu itibari ile yarı kurak iklim koşullarının Türkiye'nin \%37,3'ünde hâkim olduğu bilimsel çalışmalarla ortaya konulmaktadır (Türkeş, 2012; Öztürk, 2012). Bu durumun tarımsal faaliyetlerinin aktif olarak yürütüldüğü bir ülkede yalnızca çevresel değil; aynı zamanda ekonomik, sosyal ve kültürel bakımdan ciddi sorunlara yol açabileceği öngörülmektedir.

Günümüzde meteorolojik faktörlerin zaman ve mekân bakımından önemli değişiklikler göstermesine bağlı olarak yetiştirilen ürünlerin kalitesinde düşüş ve ürün verimliliğinde azalmalar görülmektedir. Bunun yanı sıra, mevcut toprak varlığının \%31'inde tarımsal faaliyetlerin aktif olarak yürütüldüğü ülkemizde son 10 yılda tarım alanlarının önemli ölçüde azaldığı tespit edilmiştir. Tarım alanlarına ve faaliyetlerine ilişkin bahsedilen tüm bu tespitlerin doğal sonucu olarak, kuraklığın yaşandığı bölgede zamanla tarımsal ürün üretiminden vazgeçip arazilerin terkedilmesi, ekonomide zayıflama, tarımla uğraşan çiftçinin bulunduğu bölgeyi terk etmesi ve beraberinde tarım alanlarına yapılan kentleşme baskısını da beraberinde getirmesi gibi olumsuz durumlar yaşanmaktadır (Kapluhan, 2013; Başoğlu ve Telatar, 2013).

\subsection{Kuraklık Çeşitleri}

Küresel ısınmaya bağlı olarak su kaynaklarının önemli ölçüde azalması ve gözlenen diğer süreçler (çölleşme, canlı türlerinin yok olması, doğal afetlerin sayısında artış, vb.) ekolojik bozulmalara neden olmaktadır (TAKEP, 2008). Bu bozulmalardan biri de belirli bölgelerde nem miktarında gözlenen dengesizlikler ve devamında doğal bir sonuç olarak ortaya çıkan kuraklık sorunudur. Kuraklığın çeşitleri ilgili kaynak araştırmasına göre üç sınıfa ayrılmaktadır (TAKEP, 2008; URL 1, 2019). Bunlar meteorolojik kuraklık, tarımsal kuraklık ve hidrolojik kuraklıktır.

\subsubsection{Meteorolojik Kuraklık}

Meteorolojik kuraklık, genel biçimiyle, geniş bir zaman dilimi içerisinde yağışların normal değerinin altına düşmesi olarak tanımlanabilir. Nem miktarındaki azalma derecesi ve etki süresi meteorolojik kuraklığı belirler ve bölgeden bölgeye gelişiminde farklılıklar gözlenmektedir (MMO, 1999; URL 1, 2019). Türkiye'de meteorolojik kökenli afetlere yönelik yapılan araştırmada elde edilen bulgulara göre, değişen mevsim özelliklerine göre incelendiğinde, ülkemizde meydana gelen afetlerin (heyelan, sel, kuraklık, dolu, vb.) önemli ölçüde can ve mal kayıplarına neden olduğu saptanmıştır. Ayrıca, 1940 - 2010 yılları arasında ülkemizde gözlenen afet türleri arasında en kapsamlı etkiye sahip olan türlerden biri olan kuraklığın hem doğal nitelikli alanlarda hem de yapılaşmış alanlarda etkili olduğu ortaya konulmuştur (Ceylan, 2011). 


\subsubsection{Tarımsal Kuraklık}

Tarımsal kuraklık meteorolojik kuraklığın farklı özellikleri ile yakından ilişkili olduğu bilinmektedir. Toprakta bitkinin intiyacını karşılayacak miktarda su bulunmaması olarak tanımlanan tarımsal kuraklık nem kaybına, su kaynaklarında azalmaya ve bitki türlerinin büyümelerinde değişime sebep olmaktadır. Başka bir deyişle, bu kuraklık türü, ürün için gerektiği zaman toprak neminin yetersiz olması durumuna verilen isimdir (URL 1, 2019). Bilinmektedir ki, tarımsal kuraklığın meydana gelmesinde meteorolojik kuraklığın oldukça önemli bir rolü vardır. Tarımsal kuraklığı, niteliği ve etki alanı itibariyle, diğer kuraklık türleri arasında bir geçiş aşaması olarak düşünmek yanlış olmaz (Sırdaş, 2002; TAKEP, 2008).

\subsubsection{Hidrolojik Kuraklık}

Hidrolojik kuraklık türü, uzun süre devam eden yağış eksikliği neticesinde ortaya çıkan yerüstü ve yeraltı sularındaki azalmayı ifade etmektedir. Başka bir deyişle, hidrolojik ölçümler kuraklığın erkenden tespit edilmesinde bir belirleyici niteliği taşımamaktadır (Sırdaş, 2002). Bilinmektedir ki, meteorolojik kuraklık sona erdikten sonra dahi hidrolojik kuraklık varlığını sürdürebilir. Hidrolojik kuraklıkta en önemli etken iklim olmasına rağmen, arazi kullanım planlamasında yapılan hatalar sonucunda arazinin verimsizleşmesi bu kuraklık türünü tetikleyen diğer bir önemli faktör olarak ortaya çıkmaktadır. Bazı bölgelerde meteorolojik kuraklığın etkisi ile yağış kıtlığı gözlenen alanların daha da genişleyebildiği tespit edilmiştir. Kentsel ve kırsal alanlarda görülen faaliyetler mevcut arazi kullanımında çeşitli değişikliklere yol açtığı için, meteorolojik kuraklığın frekansında değişim olmadığı halde, su kıtlığının frekansında önemli değişimler meydana gelmektedir (TAKEP; 2008; URL 1, 2019).

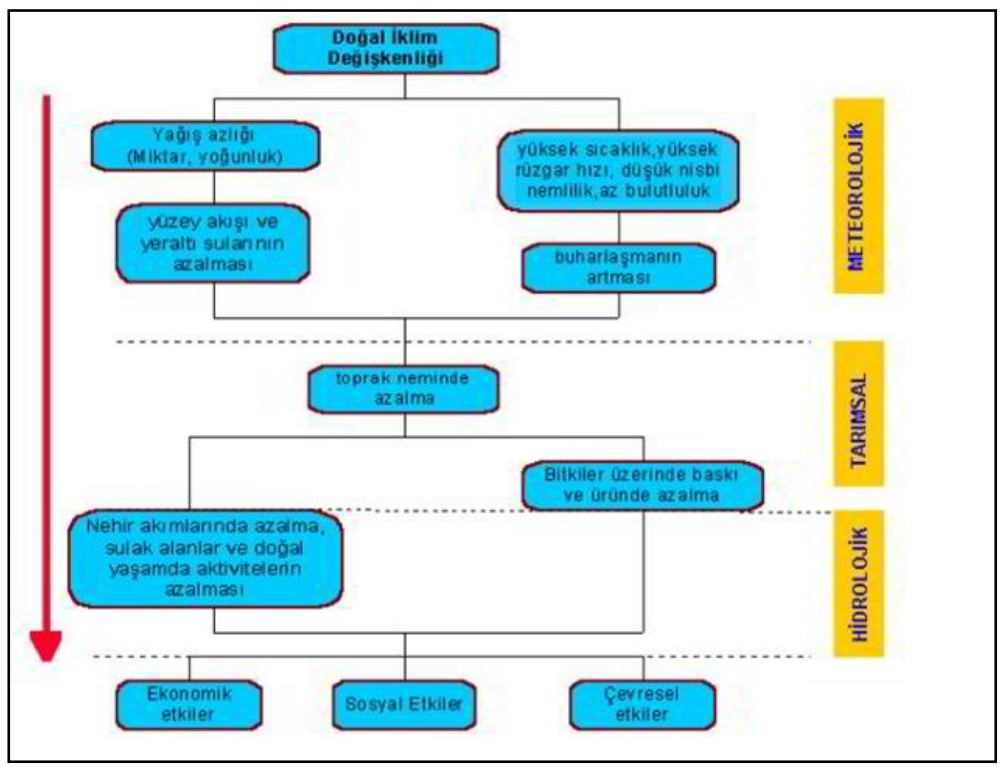

Şekil 1: Kuraklık Çeşitleri (URL1, 2019)

\section{TÜRKIYE'DE VE DÜNYADA KURAKLIK}

\subsection{Dünyada Kuraklık}

Hızla artan nüfus ve nüfus yoğunluğu, sıcaklık artışları ve doğal kaynakların geri dönüşü olmayan ve bilinçsiz biçimde kullanımı sonucu beklenen verimin alınamaması gibi sebeplere bağlı olarak dünya genelinde su stresinin yaşandığı görülmektedir. Yaşanan kuraklık sonucunda 
kimi ülkeler gerekli önlemleri almışken bazı ülkelerse durumun ciddiyetinin hala farkına varamamıştır. Kuraklık tehlikesiyle karşı karşıya kalmış olan ve su kıtlığı çeken yerleşimler arasında Avusturalya, Sao Paulo, Pekin, Miami, Kahire, vb. gibi örnekleri görmekteyiz. Bu örnekler incelendiğinde, genel olarak yaşanan kuraklık olaylarının, insanların yaşamsal koşullarını ve sosyo-ekonomik durumlarını, halk sağlığını ve ekolojik sistemleri doğrudan ya da dolaylı olarak etkilediği görülmüştür (Öztürk, 2002; Sırdaş, 2002; Türkeş, 2012).

Dünya genelinde kuraklık tehlikesiyle karşı karşıya kalan bölgeler incelendiğinde; Avusturalya'da 2018 yılında yaşanan kuraklığın hayati etkileri konusunda yerel ve merkezi yönetim temsilcilerinde farkındalık oluşmuş ve halka ülkenin bir "kuraklık diyarı" haline geldiği yönünde uyarılar yapılmıştır. Buna ek olarak, tarımsal üretim konusunda zorluk çeken üreticiler için yardım ve destekler sağlanacağı açıklanmıştır. Bu kapsamda, hazırlanan yardım paketlerinde çiftçilere 104 milyon dolar tutarında ek ödeme ve psikolojik yardım yapılacağı belirtilmiştir. Ülkenin en kalabalık eyaleti olan ve tarım üretiminin dörtte birini yapan New South Wales eyaletinin \%99 unda kuraklık görülmektedir. İtalya'nın başkenti Roma kentinde ise 2017 yılında yaşanan kuraklık sonucunda özellikle sıcaklığın önemli ölçüde arttığı yaz aylarında turistler için vaha işlemi gören ve sokakta kalan için hayat kurtarıcı işlevi gören çeşmelerin kuraklık nedeniyle kapatıldığı bildirilmiştir (Öztürk, 2002; Sırdaş, 2002; Türkeş, 2012; URL 2, 2019).

Brezilya'nın mali başkenti ve dünyanın en büyük nüfuslu kentlerinden biri olan Sao Paulo kentinde, 2015 yılında su rezervleri bakımından yeterli kapasitenin altına düşmüştür. Yaşanan su krizinin 2016 yılında sona ereceği düşünülse de 2017 yılının Ocak ayında su rezervi beklenen miktarın \%15 altında çıkmıştır. Bu durum şehrin su arzı güvenliğini şüpheli bir hale getirmiştir. Başka bir örnek olarak, 2014 yılında Pekin kentinin 20 milyonu aşan nüfusu için sadece $145 \mathrm{~m}^{3}$ su temin edilebildiği açıklanmıştır. Dünya nüfusunun yaklaşık \%20 sine ev sahipliği yapan Çin'in temiz su kaynaklarının sadece \%7'sine sahip olduğu, yetkililerin su kıtlığı sorununa çözüm için su güzergâhı değiştirme projeleri, eğitim programları ve çok su kullanan işletmelere yönelik fiyat artışı gibi önlemleri gündeme getirdiği belirtilmiştir (Türkeş, 2012; URL $2,2019)$.

İngiltere'nin başkenti Londra kenti, su kıtlığı düşünüldüğünde akla gelen ilk dünya kentlerinden biri olmasa da, yıllık $600 \mathrm{~mm}$ yağmur alan kentte içme ve kullanma suyu olarak tüketilen suyun \%80'inin nehirlerden karşılandığı ve yerel yönetim içme suyu temini konusunda önemli sıkıntılar yaşadığı ifade edilmektedir. Öyle ki, yapılan tahminlere göre, 2040 yılında kentte ciddi biçimde su kıtlığı yaşanacağı öngörülmektedir. Kahire özelinde değerlendirme yapıldığında, dünyanın en büyük medeniyetlerinin kurulmasında büyük rol oynayan Nil Nehri'nin arıtılmamış tarımsal ve evsel atıklar sebebiyle önemli ölçüde kirlendiği ortaya konulmuştur. Dünya Sağlık Örgütü ve Birleşmiş Milletler'in öngörüsüne göre, ülkede 2025 itibariyle kritik su kıtlığı yaşanacağı tahmin edilmektedir (Türkeş, 2012; URL 2, 2019).

\subsection{Türkiye'de Kuraklık}

İnsanların geçmişten bugüne kadar olan süreçte dünyanın coğrafi özellikleri birçok defa değişmiştir. Belirli zamanlarda doğal dengenin farklı nedenlerle bozulmasına bağlı olarak iklim sisteminde büyük değişimler meydana gelmiştir. Nitekim insanlık tarihinin başladığı zamandan bugüne kadar olan süreçte yeryüzünün buzullarla kaplandığı ve doğal çevrenin bu oluşumdan önemli ölçüde etkilendiği bilinmektedir. Doğada kendi seyrinde ilerleyen süreçlerin yanı sıra 19. yüzyıl ortalarında sanayi devrimi ile beraber doğal çevrenin bozulması ve kaynak tüketiminin 
hızlanması önemli ölçüde hızlanmıştır. 21. yüzyıla gelindiğinde ise, insan aktivitelerin ölçeğinin genişlemesi ve sayısının artması sonucunda iklim özelliklerinde küresel ölçekte gözle görülür değişimlerin yaşandığını iklim bilimciler tarafından kabul edilen gerçeklerdir (Sırdaş, 2002; Türkeş, 2012; TAKEP, 2019).

İklim özelliklerinin kritik biçimde değişmesi ve doğal kaynakların kontrolsüz kullanımı sonucunda insan yaşamını hayati derecede etkileyecek meteorolojik afetler içerisinde en önemlisi olarak kabul edilen tür kuraklıktır. Türkiye, değişkenlik gösteren iklim yapısı nedeniyle özellikle küresel ısınmaya bağlı olarak görülen değişimlerden en fazla etkilenen ülkelerden birisidir. Üç tarafının denizlerle çevrili olması, engebeli bir topografyanın bulunması ve orografik özellikleri nedeniyle Türkiye'nin farklı bölgeleri kuraklıktan çeşitli derecelerde etkilenmiş ve etkilenmeye devam etmektedir (Öztürk, 2002; Türkeş, 2012). Yalnızca, iklim koşulları ve topoğrafik özellikleri değil, aynı zamanda coğrafi konum itibariyle Türkiye'nin Akdeniz Havzası'nda yer almasından dolayı iklim değişikliğinin olumsuz etkilerinden önemli ölçüde etkilendiği bilinmektedir. Bulunduğu bölgedeki yaygın olarak gözlenen riskler arasında yağış rejimlerinin değişmesi ve yağış miktarının azalması, kuraklık, yer altı sularında azalma, kıtlık, artan sıcaklıklarla beraber artan buharlaşma, sıcak hava dalgaları ve buna bağlı yaşanan kitlesel kayıplar olarak yer almaktadır (Türkeş, 2012).

Meteoroloji alanında yapılan çalışmalar göstermiştir ki, Türkiye'de $\mathrm{m}^{2}$ başına düşen ortalama yağış miktarı 66 mm'dir. Türkiye'nin kuraklık problemi bazı yıllarda normallerin altında kalan yağışların sebep olduğu bilinmektedir. Bu duruma örnek olarak, 1971 yılı şubat ayında Doğu Anadolu Bölgesi, Güneydoğu Anadolu Bölgesi ile Orta Doğu Karadeniz, İç Anadolu'nun Yukarı Kızılırmak, Konya ve Yukarı Sakarya bölümünün bir kısmı dışında Türkiye'nin neredeyse yarısında kurak koşullar görülmesi, 1974 yılı Şubat ayında Türkiye için mevcut kurak koşullar yurdun neredeyse tüm bölgelerinde hissedilmesi örnek verilebilir. Ayrıca, 1983 yılı şubat ayında Malatya'dan başlayarak Türkiye'nin kuzey doğusuna doğru şiddetlenen kurak alanların Trakya'nın Sivrihisar yöresine doğru uzandığı tespit edilmiş olup; 1991 yılı şubat ayında ise Türkiye'de kurak alanlar Trakya'dan başlayıp Doğu Anadolu Bölgesi'nde son bulduğu saptanmıştır (Sırdaş, 2002; Türkeş, 2012; Akbaş, 2014). 2001 yılının Şubat ayında çok şiddetli kuraklıkların meydana geldiği, ülkenin neredeyse bütün bölgelerinde çok şiddetli kuraklıklar yaşandığı, 2009-2012 yılları arasında yağışların normalin üzerinde olmasına karşın 2013 yılında yağışlar normallerin \%13 'ün altına düşerek kuraklık problemi yeniden gündeme geldiği belirtilmiştir (Samsunlu, 2014).

\section{KURAKLIĞIN TARIM SEKTÖRÜ ÜZERINE ETKILERI}

Kuraklık ilk olarak tarım alanlarında ve su varlığına bağlı sektörler üzerinde etkisini göstermektedir. Bu sebeple, tarım sektöründeki kuraklığın gözlenen etkilerinin diğer sektörlerden çok daha farklı olduğunu söylemek mümkündür. Tarımsal kuraklık adı verilen bu kavram, bitkilerin çıkış ve gelişme döneminde intiyaç duydukları suyun toprakta bulunamaması anlamına gelmekte olup, tarımsal verimliliği yakından etkilemektedir (Kapluhan, 2013). Verimliliği etkileyen diğer unsurlar arasında mevsimlik olarak görülen kuraklıklar, buharlaşmanın maksimum seviyede olduğu yaz aylarında sulama faaliyetlerinin az olması ve beklenmedik epizodik kuraklıklar yer almaktadır.

Tarımsal kuraklık, ürün kalitesini ciddi oranda etkilemekte olup; ekonomisi tarıma dayalı olan bölgeler için en temel sorunlardan biridir. Kuraklığın yaşandığı bölgelerde gözlenen diğer sorunlar arasında yağışların beklenen düzeyinde altında kalması, düzensiz yağış rejimleri, artan 
nüfusla beraber su kaynaklarının kontrolsüz ve plansız kullanımı, su kaynaklarının nitelik ve nicelik olarak azalmasından dolayı beklenen verimi sağlamaması gibi sorunlar yer almaktadır (TAKEP, 2008; Başoğlu ve Telatar, 2013).

Tarım alanlarını ciddi oranda etkilen kuraklık toprak varlığını etkilediği kadar toprakla uğraşan üreticiyi de olumsuz yönden etkilemektedir. Bu durum en fazla aktif olarak tarımla uğraşan ülkeleri etkilemektedir. Dünyada yaşanan kuraklıklarla başa çıkabilmek adına yerel, bölgesel ve ulusal ölçekte önlemlerin ve politikaların geliştirilmesi söz konusu olmuştur. Bu önlemler ve politikalar arasında geleneksel tarım uygulamalarının terk edilmesi, tarımsal üretimde modern metotların kullanılması, değişen iklim koşullarına göre ürün deseninin değiştirilmesi, ekili dikili tarım alanlarının genişletilmesi, sulanan tekniklerinin modern teknolojilere göre yenilenmesi, yerel bazda tarım topraklarının kabiliyetlerinin doğru tespit edilmesi, üreticilere teşvik ve destek programlarının sunulması, üreticilere gerekli eğitimlerin verilmesi yer almaktadır (Türkeş, 2012; Kapluhan, 2013).

Bu sayede tarımsal verimliliğin arttırıması, tarımsal üretime yön veren kesimin tarım topraklarını terk etmesinin önüne geçilebilmesi ve kuraklıkla doğrudan mücadele edilmesi sağlanabilecektir. Ayrıca, bu sürecin doğru biçimde yönetilmesi, yalnızca tarım alanlarının korunmasını değil, aynı zamanda ekolojik dengenin devamlılığını sağlayarak bu alanların yapılaşma baskısı altında kalmasına engel olacaktır (Türkeş, 2012; Başoğlu ve Telatar, 2013).

\section{UZAKTAN ALGILAMA VE CBS KULLANILARAK YAPILAN ÖRNEK ÇALIŞMALAR}

Kuraklığın yaşandığı bölgelerde yağışların azlığı ve su kaynaklarının yetersiz olmasından dolayı yaşanan sorunları çözmek, tarım alanlarında verimliliği ve ürün kalitesinde artışı sağlamak için sıklıkla başvurulan yöntemler arasında UA ve CBS bulunmaktadır. Son yıllarda birçok alanda etkin bir araç olarak kullanılmaya başlanan Coğrafi Bilgi Sistemleri, genel olarak, farklı alanlarda yürütülen çalışmalarda kullanılabilen bir bilgisayar sistemi olup, belli bir amaca yönelik veri toplama, depolama, işleme, güncelleme, analiz etme, kontrol etme ve haritalandırma gibi işlevleri kapsamaktadır (Carter, 1994; Maguire, 1991). Mekânsal ve mekânsal olmayan verilerin CBS uygulamalarında kullanıldığı bilinmektedir. Özellikle mekânsal verilerin elde edilmesi birkaç farklı biçimde olmaktadır. Bu teknikler arasında, UA teknikleri ve arazi kullanım planlamasında uydu fotoğraflarının kullanılarak kontrollü sınıflama yapılması yer almaktadır (Tecim, 2008; Aksu, 2007).

1990 yılında Avrupa Birliği (AB) ülkelerinde başlatılan çalışmalar ve CBS uygulamaları farklı alanlarda giderek yaygınlaşmaktadır. Bu alanlara örnek olarak iklim değişikliklerinin saptanması, sağlık ve eğitim alanında yapılan araştırmalar, afet riski analizleri, alt yapı ve üst yapı sistemleri, çevre etki değerlemesi, hava ve su kirliliğinin tespit edilmesi ve biyolojik çeşitlilik hakkında yapılan araştırmalar verilebilir (Thrall, 1997).

Akademik yazında bu teknikler kullanılarak kuraklık tehlikesiyle karşı karşıya olan bölgelerde kuraklığın zamansal ve mekânsal gelişiminin tespitinin yapılmasına yönelik pek çok araştırma yer almaktadır. Ekercin (2007) tarafından Tuz Gölü ve çevresinde uydu görüntüleri kullanılarak yapılan çalışmadan Tuz Gölü'nün su rezervindeki değişimlerin çeşitli çevresel faktörlere (nüfus artışı, küresel ısınma, kuraklık vb.) bağlı olarak gözlendiği, bu bölgede yeraltı sularının ciddi miktarda azaldığı ve toprak yüzeyinde başlayan buharlaşmanın tuz ile kaplı alanların azalmasına neden olduğu tespit edilmiştir. Çalışmada elde edilen bulgular ışığında, Tuz Gölü ve 
çevresinde önceki dönemlerde yaşanan kuraklığın bir benzerinin bu dönemde tekrarlandığı, alanda yeni işletmelerin açılması, mevcut su ve tuz rezervinin kontrollü ve planlı şekilde yönetilmemesi gibi sebeplerle kuraklık probleminin kritik bir noktaya geldiği ve kuraklığa yönelik acil eylem planının mutlaka yapılması gerektiği ortaya konulmuştur (Ekercin, 2007).

Benzer biçimde, Seyhan Havzası'nda pek çok gözlem istasyonundan alınan veriler ve CBS yöntemleri kullanılarak elde edilen sonuçlara göre, kuraklığın havzanın önemli bölümünü etkisi altına aldığı ve havza için ciddi bir risk oluşturduğu saptanmıştır (Keskiner vd., 2016). Trakya Bölgesi'nde Delibaş vd. (2016) tarafından yapılan araştırmada ise meteorolojik kuraklık ve etkileri üzerine çalışmalar yapılmış olup; CBS ortamında jeo-istatistiksel yöntemler kullanılarak yağış rejimlerinin değiştiği, yağış miktarında meydana gelen bu değişimlerin tarımsal üretimi olumsuz etkilediği, bazı ürünlerde verim kaybının $\% 40$ - 50 oranına ulaştığı tespit edilmiştir (Delibaş vd., 2016). Bunlara ek olarak, sıcaklığın özellikle yaz aylarında önemli ölçüde yükselmesi sebebiyle kuraklığın etkisinin daha net biçimde gözlendiği çalışmanın bulguları arasındadır.

Durduran (2010) tarafından Konya İli'nde yer alan göl, sazlık ve barajlardaki su yüzey alanlarındaki yaklaşık 20 yıllık periyotta meydana gelen değişimlerin incelenmesinin amaçlandığı çalışmada, CBS ve UA tekniklerinden yararlanılmıştır. Çalışmadan elde edilen bulgulara göre, Konya Kapalı Havzası'nda yer altı sularının iklim değişikliği sebebiyle önemli ölçüde tükenmiş olması ve tarımsal sulama faaliyetlerinde suyun kontrollü kullanımı konusunda yaşanan aksaklıklar nedeniyle bölgede kuraklık yaşanması durumu söz konusudur. CBS ve UA tekniklerinin belirtilen fiziksel ve meteorolojik değişimlerin tespit edilebilmesi amacıyla bu tip çalışmalarda kullanılmasının, bölgeye ilişkin önlemlerin alınması ve politikaların geliştirilmesi konusunda uzmanlara ve yetkili kurumlara zaman kazandıracağı ifade edilmiştir (Durduran, 2010).

Molavizadeh (2014) tarafından Türkiye genelinde kuraklık durumunun belirlenmesi amacıyla hazırlanan çalışmada, 2004 - 2013 yılları arasında Terra-MODIS uydusu aracılığıyla elde edilen uydu görüntüleri kullanılarak ve UA teknikleri yardımıyla bu görüntüler incelenerek birtakım kritik bulgulara ulaşılmıştır. Buna göre, 2007 - 2008 yılları ve 2013 - 2014 yılları arasında ciddi düzeyde meteorolojik kuraklık olduğu saptanmıştır. 2006 yılı itibariyle iklim değişikliği ve sıcaklık değerlerinde meydana gelen farklılıkların sebep olduğu kuraklık tehlikesinin özellikle İç Anadolu ve Doğu Anadolu bölgelerinde, diğer bölgelere göre, özellikle tarımsal uygulamalar bakımından daha ciddi bir sorun teşkil edeceği çalışma sonucunda öngörülmektedir (Molavizadeh, 2014).

Bagheri (2015) tarafından Fars (İran)'da yürütülen çalışmada 1994 - 2006 yılları arasında gözlenen yağış rejiminin kuraklık üzerindeki etkisinin ölçülmesi amaçlanmış olup; çalışmada yöntem olarak CBS aracılığıyla yapılan mekânsal enterpolasyon tekniği kullanılmıştır. Tarımsal uygulamaları önemli ölçüde tehdit eden kuraklık tehlikesinin Fars kentinin güneyinde başladığı ve sonraki zamanla kentin kuzeyine hızla yayıldığı ortaya konulmuştur. Elde edilen bulgular ışığında, kentin karar mekanizmasını oluşturan şehir plancıları, tarımsal ve çevresel stratejiler üreten kurum ve kuruluşların kuraklığın önüne geçilebilmesi amacıyla Fars kentinde ivedilikle harekete geçmesi gerektiği öngörülmüştür (Bagheri, 2015).

Ek olarak, Orhan ve diğ.(2013) tarafından 1984 - 2011 yılları arasında meydana gelen kuraklık etkisinin incelenmesi ve Özesmi ve Bauer (2002) tarafından sulak alanlarda yapılan incelemeler de CBS ve UA tekniklerinden yararlanılan çalışmalar arasında yer almaktadır. Bu çalışmaların ortak noktaları incelendiğinde, dönemsel olarak fiziksel mekânda meydana gelen değişimlerin 
karşılaştırmalı olarak incelenmesi amaçlanmıştır. Kuraklığa neden olan faktörlerin tespit edilmesi ve bu faktörler özelinde tematik haritaların hazırlanması gibi çalışmalar yürütülmüştür.

İncelenen çalışmalar göstermiştir ki; 'doğanın gizli tehlikesi' olarak adlandırılan ve geniş alanlarda uzun süreli etkilere sahip olan kuraklık tehlikesinin tespit edilebilmesi ve bölgenin karakteristiğine uygun (yer altı suları, toprak yapısı, tarımsal faaliyetlerin etkinliği, vb.) önlem ve politikaların geliştirilebilmesi adına CBS ve UA teknikleri oldukça yaygın biçimde kullanılmaktadır. Uydu görüntüleri kullanılarak yapılan arazi kullanım çalışmalarında farklı dönemlere ait tespitlerin karşılaştırmalı olarak incelenmesi, kuraklık tehlikesinin gözlendiği bölgelerde karar mekanizmalarında (yerel yönetim, üniversiteler, STK'lar, halk, vb.) yeterli düzeyde farkındalık oluşturulması ve dönemsel raporların oluşturulması yoluyla bölgede meydana gelen değişimin takip edilmesi konularında bu tekniklerden önemli ölçüde faydalanıldığı görülmüştür.

\section{SONUÇ VE DEĞERLENDIRME}

İnsanlığın var olduğu günden bu zamana kadar meydana gelen tüm afet türleri incelendiğinde, bu türler arasında en önemlisi ve meteorolojik afetler sıralamasında en tehlikelisi olarak bilinen kuraklığın yaratacağı olası riskler ve doğurabileceği olumsuz koşullar Türkiye'de henüz yeterince anlaşılmamıştır. Artan nüfus, nüfus ve yapılaşma yoğunluğunun artışı ve kentleşme dinamikleri göz önünde bulundurulduğunda, ülkemizde su kıtlığı sorunuyla yakın zamanda karşı karşıya kalınabileceği geleceğe yönelik öngörüler arasında yer almaktadır. Geçmiş dönemlerde yaşanan kuraklık olayları, gelecek dönemde karşılaşabileceğimiz tehlikenin habercisi niteliğindedir. Ülkemiz konumu itibariyle de küresel ısınmanın etkilerinden en fazla oranda etkilenecek ülkeler arasındadır. Bu durum kuraklık konusunda bir an önce önlemlerin alınması gerektiğinin sinyalleridir.

'Doğanın gizli tehlikesi' olarak adlandırılan kuraklığın bir doğal afet türü olarak ivedilikle ve geniş kapsamlı biçimde önlem alınması gereken bir konu olduğu ortadadır. Bu önlemler kısa, orta ve uzun vadede farklı paydaşların katkılarıyla gerçekleştirildiği takdirde hayata geçirilebilir ve uygulanabilir. Geliştirilebilecek stratejiler arasında kuraklıkla mücadele edilebilmesi için ülke genelinde sistemli bir afet planlaması sürecinin hayata geçirilmelidir. Bahsedilen afet planlaması nitelik olarak bir tür kriz yönetimi değil, daha geniş bir bakış açısıyla, modern afet planlaması çerçevesinde ortaya konulan risk yönetimi biçiminde ele alınmalıdır. Bunun yanı sıra, yapılan planlar sonucunda devlet, sivil toplum kuruluşları ve halk için bilinçlendirme çalışmalarının yapılması ve durumun ciddiyetinin herkes tarafından anlaşılmasının sağlanması amaçlanmalıdır. Mevcut tarım alanları üzerindeki kentleşme baskısını azaltması için strateji ve eylemler geliştirilmelidir.

Türkiye'nin mutlak ve göreceli konumu dikkate alındığında, mevcut bitki örtüsündeki çeşitlilik ve su kaynaklarının varlığı azımsanmayacak kadar fazladır. Yakın gelecekte olası bir kuraklık sonucunda etkilenecek bölgelerin önceden tespit edilmesi ve gerekli önlemlerin alınabilmesi için CBS ve UA gibi etkin yöntemlerin kullanılması zaman, maliyet, alan büyüklüğü baz alınarak geniş kapsamlı çalışmaların yürütülmesi, mekânsal ve niteliksel verilerin planlı ve kontrollü şekilde bilgiye dönüştürülmesi bakımından yetkili uzman, kurum ve kuruluşlara önemli avantajlar sağlayacaktır. Özellikle kuraklık tehlikesiyle karşı karşıya olan bölgelerde uydu görüntüleri kullanılarak yapılacak karşılaştırmalı analizler aracılığıyla etkin ve yere özgü önlemlerin alınması sağlanabilir. Buna ek olarak, teknolojik yenilikler kullanılarak tarımsal sulamada modern 
tekniklerin tercih edilmesi, su yönetiminin planlı ve kontrollü biçimde gerçekleştirilebilmesi, iklim koşullarına göre ürün deseninin bölgesel olarak değiştirilmesi, kuraklığa dayanıklı bitkilere ilişkin güncel envanterin çıkartılması ve bitki yönetimi konusunda çalışmalar yapılması, verimli tarım alanlarının korunması ve mevcut ekili dikili tarım alanlarının genişletilmesi, üreticilere gerekli teşvik, destek ve eğitim programlarının sunulması gibi strateji ve politikalar kuraklıkla mücadele kapsamında değerlendirilmelidir.

Ayrıca, kuraklıkla mücadelede acil eylem planlarının hazırlanması, erken uyarı sistemlerinin geliştirilmesi, eğitim ve yayın yoluyla kuraklık tehlikesi ile ilgili farkındalık oluşturulması, sürdürülebilir ve uygun arazi yönetim planlamasının yapılması, kuraklık gözlenen bölgelerde arazi kullanım planlamasının yanı sıra geçim planlamasının yapılması, orman yangınlarına karşı üst düzey tedbirlerin alınması, konuya ilişkin gerekli yasal düzenlemelerin yapılması, halihazırda işletilmekte olan ÇATAK programının etkinliğinin arttırılması, devlet yatırımlarında kuraklık gözlenen bölgelere öncelik verilmesi, ekili ve dikili alanlarda su yönetiminin daha hassas biçimde yapılması gibi yerel, bölgesel ve ulusal ölçekte yürütülebilir çalışmalar ve stratejiler kuraklıkla mücadele sürecinde önemli planlama araçları haline gelebilir.

İnsanoğlu dâhil tüm canlıları etkileyen, kitlesel ölümlere sebep olabilen kuraklık ile mücadelede kriz yönetiminden kaçınılmalıdır. Bunun gerekçesi olarak, uygulanacak kriz yönetimi stratejilerinin tepkisel ve zamansız olması, eşgüdüm içermemesi, afetin felakete dönüşmesine sebep olabilmesi belirtilebilir. Tüm doğal afetlerde uygulanması gereken ve özellikle insan yaşamına doğrudan her anlamda etkisi olan kuraklık için modern afet yönetim planlarının oluşturulması gerekmektir (Büyükbaş ve Ormanoğlu, 2013).

Alınacak önlemler ve geliştirilecek doğru stratejiler sayesinde kuraklığın etkisiyle meydana gelebilecek su kıtlığı, bitki çeşitliliğinde daralma, tarım topraklarının kentleşme baskısı altında daralması gibi önemli ve canlı yaşamını direkt olarak etkileyen çevresel problemler ciddi şekilde bertaraf edilebilir. Unutulmamalıdır ki, kentleşme süreçleri doğal çevrede meydana gelen değişimlerden bağımsız düşünülemez. Karar mekanizmalarının (merkezi yönetim, yerel yönetim, üniversiteler, STK'lar, halk, vb.) şehir planlama sürecinde karşı karşıya kalınan bu afet riskiyle mücadelesinde mevcut durumun net biçimde ortaya konulması, tespit ve analizlerle gözlemlerin desteklenmesi, planlı ve kontrollü olarak afetin etkilerinin azaltıması, kuraklık konusunda farkındalık yaratılması ve ülkemizde temel geçim kaynaklarından biri olan tarımsal üretim süreçlerinde verimin düşmemesi adına oldukça önemli bir yer teşkil etmektedir. 
Küresel İklim Değişikliğinin Kaçınılmaz Sonucu: Kuraklık

An Inevitable Consequence of Global Climate Change: Drought

\section{KAYNAKLAR}

Akbaş, A. (2014). Türkiye Üzerindeki Önemli Kurak Yıllar, Coğrafi Bilimler Dergisi, 12 (2), 101 118.

Bagheri, F. (2015). Mapping Drought Hazard Using SPI Index and GIS: Case Study Fars Province, Iran. Yüksek Lisans Tezi, İstanbul Teknik Üniversitesi, Fen Bilimleri Enstitüsü.

Başoğlu, A., Telatar, O.M. (2013). Iklim Değişikliğinin Etkileri: Tarım Sektörü Üzerine Ekonometrik Bir Uygulama, Karadeniz Teknik Üniversitesi Sosyal Bilimler Enstitüsü Dergisi, 6.

Bryant, E. A. (1993). Natural Hazards, Cambridge University Press.

Büyükbaş, E., Ormanoğlu, B. (2013). Afetler ve Afet Yönetiminde Meteorolojinin Yeri, Türkiye İdare Dergisi, 476.

Carter, G.F.B. (1994). Geographic Information Systems For Geoscientists: Modelling with GIS. Computer Methods in The Geosciences, 13. United Kingdom: London.

Ceylan, A. (2011). Meteorolojik Karakterli Doğal Afetler ve Türkiye, MGM, Ankara.

Delibaş, L., Albut, S., Bağdatlı, M.C. (2016). Trakya Bölgesinde Uzun Yıllar Yağış ve Sıcaklık Değişimlerinin Coğrafi Bilgi Sistemleri (CBS) Kullanılarak Kuraklık Açısından Değerlendirilmesi, Proje Raporu, Namık Kemal Üniversitesi.

Durduran S. S. (2010). Coastline change assessment on water reservoirs located in the Konya Basin Area, Turkey, using multitemporal landsat imagery, Environmental Monitoring and Assessment, 164, 453-461.

Ekercin, S., Orhan, O. (2014). Konya Kapalı Havzası'nda Uzaktan Algılama ve CBS Teknolojileri ile İklim Değişikliği ve Kuraklık Analizi, Yüksek Lisans Tezi, Aksaray Üniversitesi, Fen Bilimleri Enstitüsü.

Kadıoğlu, M. (2011). Afet Yönetimi Beklenilmeyeni Beklemek En Kötüsü Yönetmek, Marmara Belediyeler Birliği, İstanbul.

Kapluhan, Erol. (2013). Türkiye'de Kuraklık ve Kuraklığın Tarıma Etkisi, Marmara Coğrafya Dergisi, 27.

Keskiner, A.D., Çetin, M., Uçan, M., Şimşek, M. (2016). Coğrafi Bilgi Sistemleri Ortamında Standardize Yağış Indeksi Yöntemiyle Olasılıklı Meteorolojik Kuraklık Analizi: Seyhan Havzası Örneği, Çukurova Tarım Gıda Bil. Dergisi, 31(2), 79-90.

Maguire, D.J. (1991). An Overview and Definition of GIS. London: Longman.

MMO (1999). Meteorolojik Karakterli Doğal Afetler ve Meteorolojik Önlemler Raporu, Ankara.

Molavizadeh, N. (2014). Determinantion of Drought Conditions in Turkey between 2004 and 2013 Using Indices Derived from Remotely Sensed Data, Yüksek Lisans Tezi, İstanbul Teknik Üniversitesi, Fen Bilimleri Enstitüsü.

Orhan O., Ekercin, S., Dadaser-Celik, F. (2014). Use of Landsat land surface temperature and vegetation index products for monitoring drought in Salt Lake Basin Area, Turkey. The Scientific World Journal, 11.

Özesmi S. L., Bauer, M.E., (2002). Satellite remote sensing of wetlands, Wetland Ecology and Management, 10, 381-402. 
Öztürk, K. (2012). Küresel Iklim Değişikliği ve Türkiye’ye Olası Etkileri, Gazi Eğitim Fakültesi Dergisi, 22,1.

Sırdaş, S. (2002). Meteorolojik Kuraklık ve Türkiye Modellemesi, İstanbul Teknik Üniversitesi Dergisi, 2 (2) ,95-103.

Şimşek, O., Çakmak, B. (2010). Su Bütçesi Yöntemiyle Buğday Üretimi Risk Analizi. Kahramanmaraş Sütçüimam Üniversitesi Ziraat Fakültesi Tarımsal Yapılar ve Sulama Bölümü, Cilt:1, 431-441.

Tarım ve Köyişleri Bakanlığı Antalya İı Müdürlüğü (2008). Antalya Tarımsal Kuraklık Eylem Planı (TAKEP), Ankara.

Thrall, S.E. (1999). Geographic Information Systems (GIS) Hardware and Software. Journal of Public Health Management and Practice, 5 (2), 82 - 90.

Türkeş, M. (1994). Artan Sera Etkisi ve Türkiye Üzerindeki Etkileri, TÜBiTAK Bilim ve Teknik Dergisi, 349, Ankara.

Türkeş, M. (1996). İklim Değişiklikleri ve Ekosistemler Üzerindeki Olası Etkileri, TÜBiTTAK Bilim ve Teknik Dergisi, 321, Ankara.

Türkeş, M. (2008). Gözlenen iklim değişiklikleri ve kuraklık: Nedenleri ve geleceği, Toplum ve Hekim 23, 97-107.3.

Türkeş, M. (2012). Türkiye'de Gözlenen ve Öngörülen Iklim Değişikliği, Kuraklık ve Çölleşme, Ankara Üniversitesi Çevre Bilimleri Dergisi, 4 (2), 1-32.

URL 1: www.mgm.gov.tr, Erişim Tarihi: Eylül 2019.

URL 2: www.bbc.com, Erişim Tarihi: Eylül 2019. 